\title{
Foreign Direct Investment - Domestic Investment Nexus: Evidence from India
}

\author{
Abraham Babu
}

\begin{abstract}
The relationship between foreign direct investment and domestic investment is intriguing. An important question arises - does foreign direct investment crowd in or crowd out domestic investment? This paper examines this nexus in the post-1991 period in India, which is also considered as the post-reform period. It is during this era; the above-mentioned topic gains more impetus as the economy opened up for further foreign inflows. The time period taken for the paper was from 1990-91 to 2014-15. The data series were checked for stationarity and the presence of long run relationship between foreign direct investment and domestic investment was analysed using cointegration test. Thereafter, the vector error correction model was estimated. The results clearly show that foreign direct investment crowds out domestic investment in India in the post reform period. The findings have significant policy implications because there is a substituting relationship between foreign direct investment and domestic investment in India.
\end{abstract}

KEY WORDS: $\quad$ Foreign direct investment, domestic Investment, stationarity, cointegration, vector error correction model.

JEL Classification: F21, E22, C32.

'Assistant Professor, Rajagiri Business School, Rajagiri Valley P.O. Kakkanad, Cochin, 682039, Kerala, India.

\section{Introduction}

The significance of Foreign Direct Investment (FDI) has become even more pronounced and has spread rapidly throughout the global economy since the 1990s. There has been a surge in FDI inflows to the developing economies (World Bank, 2002). The role of FDI and its influence in these economies have become more prominent now. It has been widely debated whether the host countries received substantial benefits even after allocating their scarce resources. Again, whether these countries are able to exploit FDI inflows in their development strategies. At the same time, domestic savings and investment may not have the same impact on growth in more open economies. Therefore, the level of openness of an economy would

Correspondence concerning this article should be addressed to: Abraham Babu, Rajagiri Business School,

Rajagiri Valley P.O. Kakkanad, Cochin, 682039, Kerala, India.

E-mail:abraham@rajagiri.edu influence investments, both domestic and foreign. In this context, it is important to examine the relationship between foreign direct investment and domestic investment (DI) in India. The country, during the early 1990s, started opening up to foreign investments. It is often argued that the inflow of FDI which ensued, considered as the post reform period, have helped India supplement its DI. However, there is lack of enough empirical evidence on the relationship between DI and FDI in India. Thus, this paper tries to explore the long run relationship between the above-mentioned variables.

Whether FDI crowds in or crowds out domestic investment in the host country is a debatable issue. The domestic investment climate, the prevailing trade and industrial policy regimes of the host country can influence the FDI inflows and its impact on the domestic investment in the host country. On the one hand, FDI could crowd out those domestic investors who were protected by 
the previous policies. They may find it difficult to compete with the technologically advanced and efficient foreign investors. On the other hand, FDI inflows could crowd in domestic investment by creating spillover effects. This can be through the diffusion of the latest technologies and production linkages both forward and backward. The policy regime in India in the post reform period included liberalised approval from the Government and the raised limits to the levels of FDI. This was expected to bring about a complementary link between FDI and DI. But the inherent conditions like rigidities in the financial system, excessive dependence on saving for domestic capital formation are likely to bring about a substituting relation between these variables. In this article, the relationship between FDI and domestic investment is examined for India for the period 1990-91 to 2014-15. Using the Vector Error Correction model (VECM), the presence of long run relationship between FDI and domestic investments is analysed. The variables used for FDI and domestic investment are the part of FDI inflows in Gross Domestic Product (GDP) and the part of Gross Domestic Capital Formation (GDCF) in GDP respectively. Along with these major variables, certain control variables were also used in the analysis.

The remainder of this paper is structured as follows, with Section 2 outlining the related theoretical background. The data and the methodology are explained in the next section. The results are presented in Section 4 and the conclusions are summarised in the final section.

\section{Literature Review}

After the early 1990s, there has been a series of policy initiatives from developing economies to attract FDI flows. The economies focused on how to optimally utilize their scarce resources and employ their idle resources. For this, these economies embarked on making changes in their macroeconomic policies to attract more FDI. It was aimed at generating employment, adopting the latest technology and to reach out to the world market. Even then, these developing economies had two major apprehensions related to FDI inflows. The first was the fear regarding the volume, the mode and the use of transferred resources benefiting less than an alternative way of resource allocation. Second, they were apprehensive about foreign firms having better bargaining power than the domestic firms in both local and global markets (Dunning, 1981).

This led to the debate on whether FDI crowds in or crowds out Domestic Investment. According to the crowding in hypothesis, FDI inflows crowd in domestic investment and would lead to fresh or higher levels of domestic investment. This is advantageous to the host country because FDI inflows can contribute to their capital formation. This can also be through the introduction of new goods and latest technologies. Whether FDI inflows crowd in or crowd out domestic investment can be found by examining the effect on the gross fixed capital formation, which comprises of both foreign and domestic investments. If there is one unit increase in gross fixed capital as a result of a one unit increase in FDI, domestic investment remains unchanged and FDI influence is neutral. Again, a unit increase in FDI inflows leads to more than one unit increase in total capital formation, crowding in occurs through the stimulation of domestic investment. Crowding out occurs when a unit increase in FDI decreases the total capital formation or if the increase in total investment becomes smaller than the increase in FDI (Agosin \& Machado, 2005).

Crowding in of domestic investment generally happens when foreign investment generates spillovers in the host economy. Normally, these spillovers happen because foreign investments reduce the costs of imbibing the latest technologies, which in turn enhances the growth rate in the host country (Borensztein et al., 1998). The marginal productivity of investments in the specialised inputs increases when FDI generates demand for them.

Gallagher and Zarsky (2007) categorize the crowding in effect into different channels. The local supply of inputs to the foreign investors contributes to the backward linkages. The forward linkages happen when domestic firms use efficiency-enhancing inputs supplied by foreign firms. The knowledge spillovers happen when domestic firms gain access to new technologies and knowhow from foreign firms thus bringing about the crowding in effect. When FDI enters the host country, multiplier effects can be observed. When foreign firms employ more people 
from the host country, it can lead to a surge in the demand for the goods and services produced by the local firms.

Likewise, crowding out of domestic investment might also happen in many ways. Foreign firms may borrow from domestic financial markets at higher interest rates which results in the crowding out of domestic firms. Again, foreign investors can also bring about adverse knowledge spillovers when they start employing the local talent to the disadvantage of domestic firms. It is also observed that the foreign firms may also usurp the available investment opportunities of the domestic firms (Agosin \& Machado, 2005).

Various strands in economic theory explain the diverse channels through which FDI could influence capital accumulation in the host countries. The effects on capital formation by FDI can be both direct and indirect. The direct effect happens when FDI is considered as a financial flow contributing to the capital stock accumulation. This adds up to the domestic investment. The impact of FDI largely depends on the entry mode of Multi-National Enterprises (MNEs). They create new capital assets and have a direct impact on capital formation. The impacts of FDI on capital formation depending on the entry mode of MNEs in the host economies have been highlighted in the literature. Empirical studies based on macro data could not separate the impacts by different entry modes. There was a sudden increase in the number of Mergers and Acquisitions (M\&A) in the developing countries in the 1990s. Recently, Ashraf and Herzer (2014) have explored the different impacts of Greenfield investment and M\&A on domestic investment. Aggregate data from UNCTAD database on FDI was used. The results confirmed that M\&A do not significantly impact domestic investment. However, Greenfield investments had a crowding out effect on domestic investment.

It is envisaged that FDI flows bring in the capital as well as the knowhow. FDI in developing countries brings in the requisite capital along with intangible assets. FDI can be advantageous to the domestic investment in the host countries in a number of ways as given by theory. Firstly, MNCs usually have greater access to the information and the financial resources than the domestic firms in the developing countries. Hence, these firms are in a better position to detect and exploit the opportunities than the domestic firms. Secondly, foreign firms highlight the need for more efficient infrastructure facilities like telecommunication, transportation etc. It is obvious that poor or insufficient infrastructure is a constraint to the development of business in these countries. The foreign firms can either finance these projects or can be directly involved in providing the required infrastructure. Thirdly, foreign firms can contribute to domestic capital formation, through the supply of scarce inputs (Helleiner, 1988). They can channelize these by importing capital, technology and other intangible inputs. Fourthly, positive externalities are realized when there is increased availability of information, skillsets and foreign market access which may be beneficial to the domestic firms (Moran et al., 2011). Fifthly, the foreign firms may create demand for local firm inputs which can substitute the imports from the home countries (Gorg \& Greenaway, 2002). Finally, FDI inflows can contribute to the additional tax revenue invested in public goods.

Relatively, the empirical evidence on the relation between FDI and domestic investment has been obvious. Cumulative measures of investment are used in these studies, either for one particular country or a panel of countries. Fry (1993) was among the first to analyse a panel of countries. The data from 16 countries were used to show that FDI can have either a positive or a negative impact on domestic investment. The impact was influenced by the level of trade barriers and financial regulations of the host country. Most of the studies showed the direct relation between FDI and proxies for domestic investment. Some recent works have provided further insights. Morrissey and Udomkerdmongkol (2012) demonstrated that the crowding out effect of FDI on private investment is stronger in countries with higher political stability. Farla et al. (2014) contributed to the same issue with a better implementation of a system of Generalized Method of Moments (GMM). A lesser artificial measure of domestic investment was also adopted to investigate whether the results revealed in the literature were robust to such changes. By doing so, it was concluded that foreign investment has a positive effect on total investment. It was also found that there was no moderating role of good governance in 
the relation. Starting with similar findings, Munemo (2014) suggested that such positive impact of FDI is conditional on the existence of a good investment climate.

Prasanna (2010) found that FDI inflows neither crowds in nor crowds out DI in India from 1991-92 to 2006-07. Ranjan et al., (2012) observed that the contribution of capital inflows to gross domestic capital formation variation increased over the years. Rath and Bal (2014) established that for the period 1978-79 to 2009-10, FDI had crowding in effects on Private Domestic Investment. The shocks in Private Domestic Investment clearly enhanced the FDI inflows in India. From the above discussion, it can be observed that neither the theoretical background nor the empirical evidence provides a conclusive picture about the impact of FDI on domestic investment. On the whole, the empirical evidence appears to propose that FDI has a positive impact on domestic investment. This needs to be explored further in the Indian context.

\section{Data and Methodology}

Data for the analysis is drawn from the Reserve Bank of India, Handbook of Statistics on Indian Economy. The period taken was from 1990-91 to 2014-15. The analysis was started from 1991 because during this period, there was an important policy break (economic reforms). Consistent long data was available after low levels of FDI initially. Since the analysis covers a longer time period, these low levels do not affect the results.

In this paper, initially, Feldstein and Horioka model (1980) is used to examine the long run relationship between domestic saving and investment in India, which is specified as,

$\left(\frac{I}{Y}\right)_{t}=\alpha+\beta\left(\frac{S}{Y}\right)_{t}+e_{t}$

Where $\left(\frac{I}{Y}\right)_{t}$ and $\left(\frac{S}{Y}\right)_{t}$ are the ratio of gross domestic investment to gross domestic product and the ratio of gross domestic saving to gross domestic product, and et is the disturbance term. In equation 1 , the coefficient $\beta$ is the Feldstein-Horioka coefficient or the link between domestic savings and investment.

The value of $\beta$ ranges from 0 to 1 . If $\beta=1$, there is perfect correlation between domestic investment and domestic savings. This means that there is no foreign investment in the country, i.e., capital mobility is zero. The other extreme case is when $\beta=0$, which implies that domestic investment is fully financed by foreign capital. This indicates perfect capital mobility. Though $\beta$ in India showed low capital mobility, it was also found that both FDI inflows and savings affect investments in India. This points to the complementary relationship between investments and FDI. However, the simple OLS estimation yielded biased results, due to spurious regression problem and auto correlation issues. So, OLS method was found inappropriate. In order to address these issues, the Vector Error Correction Model (VECM) is used. The details of the model are discussed as follows.

\subsection{VECM methodology}

To start with the VECM estimation, it is important to ensure that the variables are integrated of the same order say one i.e., I (1). Therefore, a unit root test is conducted for each variable in the model. Augmented Dickey Fuller (Dickey \& Fuller, 1979) test is the most popular test for stationarity. Unit root test is performed on the time series macroeconomic data because most of them have unit roots. Regressing non-stationary series on one another is likely to yield spurious results. Mean reversion and finite variance will confirm whether the variable shows a unit root. So, the initial step is to test the nature of the time series to determine whether it is stationary or nonstationary and the order of integration. The order of integration helps in determining the successive long run relationship between the variables.

The next step is to check for an optimal lag length. This is important because the result of the Vector Autoregressive (VAR) model can be quite sensitive to the lag length. The Akaike Information Criterion (AIC) or the Schwarz Information Criterion (SIC) can be used to select an appropriate lag length. The latter is preferred over the former as it selects longer lags which is likely to show the effects of the Independent Variables (IVs), in the current period, over a longer time. In the sense, lagged effects of IVs may persist, rather than the immediate impacts.

Thereafter, cointegration among the series can be tested which shows the presence of a linear combina- 
tion of non-stationary variables that are stationary. The presence of cointegration suggests that there exists a stationary long run relationship among the series. Conversely, the absence of cointegration implies that the linear combination is not stationary. The procedure implemented in this paper was developed by Johansen and Juselius (1990). It is a representation of the approach of analyzing multivariate cointegrated systems. This procedure is preferred over the Engle Granger static procedure. The advantage of the Johansen Vector Auto-Regressive (VAR) procedure is that it allows the simultaneous evaluation of multiple relationships. Again, it does not impose any prior restrictions on the cointegration space. The Johansen cointegration approach tests for the cointegration rank for a VAR process. It estimates the TRACE and LMAX stats, the Eigen values, and the eigenvectors also. It sums up the long run equilibrium coefficients, the adjustment coefficients and the covariance matrix of the errors. The R-squares for each of the equations in the VECM can also be found. Again, linear restriction on the long run equilibrium coefficients is also tested. Hence, the method consists of full information maximum likelihood estimation of a system categorized by $\mathrm{n}$ cointegrating vectors. Let $\mathrm{rt}$ such that $t=1 \ldots \mathrm{T}$, where a vector of random variables represented by ( $\mathrm{px} 1)$, where $\mathrm{p}$ is the number of jointly endogenous variables, follows a $\mathrm{p}$-dimensional VAR model with Gaussian errors. Now, the conditional model can be written (which is restrictive on the observations $\mathrm{Z}-\mathrm{k}+1,---$, $\mathrm{z}$ which are fixed) as:

$r_{t}=\beta_{1} r_{t-1}+\ldots+\beta_{k} r_{t-k}+\mu+\gamma C_{t}+\varepsilon_{t} \ldots$

Here, $\beta_{1}, \ldots \beta_{\mathrm{k}}$ are $\mathrm{p}$ by $\mathrm{p}$ matrices, $\mu$ is the vector of constants and $C_{t}$ is a vector of non-stochastic variables. If cointegration exists between the variables in $r_{t}$, the model can be written in error correction form as:

$$
\begin{aligned}
& \Delta r_{t}=\lambda_{1} \Delta r_{t-1}+\ldots+\lambda_{t-1} \Delta r_{t-k-1}+\pi r_{t-k}+\mu+\gamma C_{t}+\varepsilon_{t} \\
& t=1 \ldots . . . .
\end{aligned}
$$

Where $\lambda i=-\left(I-A_{1} \ldots-A_{i}\right)$, for $i=1 \ldots k-1$; and $\pi=-$ $\left(\mathrm{I}-\mathrm{A}_{1} \ldots-\mathrm{A}_{\mathrm{k}}\right.$ )

The models in equations (2) and (3) are the vector error correction models for the cointegrated series. The short run relationships of the variables in the system are denoted by the series in differences whereas the long run relationships by the variables in levels. A shock to the ith variable not only affects itself directly but also the other endogenous variables through the dynamic structure of the VAR.

The VAR model can be represented as follows:

$$
\begin{aligned}
& \Delta \mathrm{Y}_{t}=\gamma_{y}+\sum_{i=1}^{\eta} \alpha_{i} \Delta \mathrm{Y}_{t-i}+\sum_{j=1}^{\eta} \beta_{j} \Delta \mathrm{X}_{t-j}+\varepsilon_{1 t} \\
& \Delta \mathrm{X}_{t}=\gamma_{x}+\sum_{i=1}^{\eta} \delta_{i} \Delta \mathrm{Y}_{t-i}+\sum_{j=1}^{\eta} \varphi_{j} \Delta \mathrm{X}_{t-j}+\varepsilon_{2 t}
\end{aligned}
$$

The two equations constitute a vector auto regression model in first differences. In equations (4) and (5), $\mathrm{Y}$ and $\mathrm{X}$ are dependent and independent vectors of variables respectively. As it involves a VAR model structure, the same variable which appears as dependent variable in (4) appears as independent variable in (5) and vice-versa. Both $\alpha_{i}$ and $\Phi_{j}$ coefficients play a very vital role in guiding the lagged impact of one variable on the same variables while $\delta_{i}$ and $\beta_{j}$ coefficients determine the lagged impact of one on the other variables. VAR devices have been used for testing the sources of variability. It may be noted that at least one of the coefficients in the both equations (4) and (5) should be significantly different from zero to become a VAR model. Once the coefficients confirm to such conditionality, then it will be easier to know the impact of one variable on the other.

\section{Results}

This paper tries to study the long run equilibrium relationship among the variables by applying the Johansen cointegration test. As testing the unit root properties of the variables is considered as the necessary condition for testing the cointegration among them, the Augmented Dickey-Fuller (ADF) unit root test is applied to check the integrating properties of the variables. The results are given in Table 1.

From the results of the ADF test at different levels, it is evident that all the variables exhibit unit root in levels and are stationary in first difference. Now it would be ideal to test the long run relationship between variables, using cointegration. The results of the Johansen cointegration test are presented in Table 2 . 
Table 1

Augmented Dickey-Fuller Test Results

\begin{tabular}{lcc}
\hline Variable & Level & 1st difference \\
\hline FDI & -0.348269 & -0.805920 \\
& $(-2.291919)$ & $(-3.6480)^{* *}$ \\
Saving & -0.298617 & -1.234166 \\
& $(-1.691967)$ & $(-5.81312)^{\star}$ \\
Investment & -0.422447 & -1.105420 \\
& $(-2.313753)$ & $(-4.97423)^{\star}$ \\
\hline
\end{tabular}

Note: ${ }^{\star}$ Represents significance at $1 \%$ level, ${ }^{\star *}$ Represents significance at $5 \%$ level.

Source: Author's own estimation based on data obtained from the Reserve Bank of India, Handbook of Statistics on Indian Economy (1990-91 to 2014-15).

Table 2

Johansen Cointegration Test Results

\begin{tabular}{lccc}
\hline \multicolumn{5}{c}{ Trace statistics } \\
\hline Null & Alternative & Statistics & $95 \%$ critical value \\
$\mathrm{r}=0$ & $\mathrm{r} \geq 1$ & $42.06614^{*}$ & 29.79707 \\
$\mathrm{r} \leq 1$ & $\mathrm{r} \geq 2$ & 14.11488 & 15.49471 \\
$\mathrm{r} \leq 2$ & $\mathrm{r} \geq 3$ & $3.919423^{*}$ & 3.841466 \\
& \multicolumn{2}{c}{ Maximum eigenvalue test } \\
$\mathrm{Null}$ & Alternative & Statistics & $95 \%$ critical value \\
$\mathrm{r}=0$ & $\mathrm{r} \geq 1$ & $27.95126^{*}$ & 21.13162 \\
$\mathrm{r} \leq 1$ & $\mathrm{r} \geq 2$ & 10.19546 & 14.26460 \\
$\mathrm{r} \leq 2$ & $\mathrm{r} \geq 3$ & $3.919423^{*}$ & 3.841466 \\
\hline
\end{tabular}

Note: $r$ stands for the number of cointegrating vectors; the lag length is determined by the optimum value of Akaike Information Criterion and Schwartz Bayesian Criterion. ${ }^{*}$ Denotes rejection of null hypothesis at $5 \%$ level of significance.

Source: Author's own estimation based on data obtained from the Reserve Bank of India, Handbook of Statistics on Indian Economy (1990-91 to 2014-15).

The results indicates that the null hypothesis of no cointegration is rejected by both the trace statistic (TS) and the eigenvalue statistic (ES) at 5\% level of significance. Further, both the TS and ES results show that there exists at least one cointegrating vector among the variables. This implies that the variables taken viz., FDI, investment and saving are cointegrated. In other words, the results indicate that there exists a long run equilibrium relationship between FDI, domestic investment and saving. It is clear that these variables share a common trend in the long run.
The result of the Johansen cointegration test between FDI and domestic investment also indicate that there is no long run relationship between the two variables. But, the long run relationship is more pronounced for savings. In specific terms, the trace test statistics indicate 1 cointegrating equation at 5 per cent level among the series in the model.

Since there is the existence of long run relationship among the series, the next step is to estimate the Vector Error Correction Model (VECM). Table 3 shows normalised cointegrating coefficients and Table 4 shows 
Table 3

Normalised Cointegrating Coefficients

\begin{tabular}{lccc}
\hline INVST(-1) & FDI(-1) & SAVING(-1) & C \\
\hline 1.000000 & 484.2623 & -107.9353 & 2326.267 \\
& $(71.8908)$ & $(18.1621)$ & \\
\hline
\end{tabular}

Note: Standard error in ( ) and t- statistics in [ ]

Source: Author's own estimation based on data obtained from the Reserve Bank of India, Handbook of Statistics on Indian Economy (1990-91 to 2014-15).

\section{Table 4}

Coefficient of Error Correction Terms

\begin{tabular}{lcc}
\hline $\mathbf{D}$ (INVST) & D(FDI) & D(SAVING) \\
\hline-0.004698 & -0.000816 & -0.007280 \\
$(0.00417)$ & $(0.00056)$ & $(0.00298)$ \\
{$[-1.12678]$} & {$[-1.45004]$} & {$[-2.44253]$} \\
\hline
\end{tabular}

Note: Standard error in ( ) and t- statistics in [ ]

Source: Author's own estimation based on data obtained from the Reserve Bank of India, Handbook of Statistics on Indian Economy (1990-91 to 2014-15).

the coefficient of error correction terms.

The normalized cointegrating coefficients represent the long run relationship between domestic investments and the independent series in the model. It can be inferred that FDI has a negative impact whereas saving has a positive impact on DI respectively.

The coefficient of error correction terms revealed that the savings significantly influence domestic investment in India. The equation contains information about the long run relationship since the cointegrating vector does enter into this equation. The speed of the adjustment coefficient is also significant in the model. This suggests that the rate of variation of domestic investment at time $t$, which adjusts to the single long-run cointegrating relationship, can be determined.

From the table, the estimated long run effect of a 1 per cent increase of domestic saving on the domestic investment can be found out, while keeping the other variable constant. This implies that the exact impact of domestic saving on domestic investment can be ascertained.

\section{Summary and Conclusions}

The relationship between foreign direct investment and domestic investment is a contentious issue in literature. The main debatable issue revolves around the question whether FDI crowds in or crowds out domestic investment? On the one hand, by creating spillover effects, FDI may lead to new or higher amounts of Domestic Investment where it would not be possible in the absence of FDI, thus have a crowding in effect. On the other hand, due to the loss of competitiveness of the domestic firms, increase in the level of interest or adverse knowledge spillovers, FDI carries a risk of crowding out for Domestic Investment. 
In this paper, the relationship between FDI and domestic investment in India was explored since 1991 (the post-reform period). The analysis clearly showed that FDI crowds out domestic investment in the post reform period. The reasons for this crowding out effect could be diverse. Crowding out could have occurred if FDI was directed to existing projects through mergers and acquisitions. Here, FDI does not create fresh investments. It is obvious that the Indian economy was excessively protected and could not attract substantial level of FDI till 1991. FDI may also crowd out domestic investment when foreign investors enter protected sectors which were once dominated by the Government undertakings (Public Sector Undertakings) through privatisation. Given the rigidities in the financial system, this interpretation seems realistic. Again, inherently, there is saving retention and the economy was conditioned to depend less on external resources to meet the investment requirements. Finally, the domestic investors may not have the capability to compete with the more efficient foreign investors and may crowd out. The policy regime in India in the post reform period which included liberalised approval from the Government and the raised limits to the levels of FDI, has played an antagonistic role and thus led to crowding out of domestic investment. Therefore, there is the urgent need for policy changes to bring about a more complementary than substituting link between foreign and domestic investments. It may not be possible to go for these changes if the above -mentioned arguments are ignored. This intricate connection between FDI and domestic investment in India needs to be researched further.

\section{References}

Agosin, M., \& Machado, R. (2005). Foreign investment in developing countries: Does it crowd in domestic investment? Oxford Development Studies, 33(2), 149162. https://doi.org/10.1080/13600810500137749

Ashraf, A., \& Herzer D. (2014). The effects of Greenfield investment and M\&As on domestic investment in developing countries. Applied Economics Letters, 21(14), 997- 1000. https://doi.org/10.1080/1350485 1.2014 .904482

Borensztein, E., De Gregorio, J., \& Lee, J.W. (1998). How does foreign direct investment affect economic growth? Journal of International Economics, 45(1), 115-135. https://doi.org/10.1016/S00221996(97)00033-0
Dickey, D.A., \& Fuller, W.A. (1979). Distribution of the estimators for autoregressive time series with unit root. Journal of American Statistical Association, 74, 427-431. https://doi.org/10.1080/01621459.19 79.10482531

Dunning, J. (1981). Explaining the international direct investment position of countries: Towards a dynamic development approach. Weltwritschaftliches Archiv, 119, 30- 64. https://doi.org/10.1007/978-1349-05989-8_4

Farla, K., \& Combruggher, D., \& Vertspagen, B. (2014). Institutions, foreign direct investment, and domestic investment: Crowding out or crowding in? World Development, 88, 1-9. https://doi. org/10.1016/j.worlddev.2014.04.008

Feldstein, M., \& Horioka, C. (1980). Domestic saving and international capital flows. The Economic Journal, 90, 314-329. https://doi.org/10.3386/ w0310

Fry, M.J. (1993). FDI in a macroeconomic framework: Finance, efficiency, incentives and distortions [Policy Research Working Paper No. 1141]. World Bank.

Gallagher, K. P., \& Zarsky, L. (2007). The enclave economy: foreign investment and sustainable development in Mexico's Silicon Valley. The MIT Press.

Gorg, H., \& Greenaway, D. (2004). Much ado about nothing? Do domestic firms really benefit from foreign direct investment? The World Bank Research Observer, 19(2), 171-197. https://doi.org/10.1093/ wbro/lkh019

Helleiner, G.K. (1988). Transnational corporations and direct foreign investment. Handbook of Development Economics, 2, 27. https://doi.org/10.1016/ S1573-4471(89)02014-0

Johansen, S., \& Juselius, K. (1990). Maximum likelihood estimation and inference on cointegration with application to the demand of money. Oxford Bulletin of Economics and Statistics, 52, 169-210.

Moran, T. H., Graham, E. M. \& Blomström, M. (2011). Does foreign direct investment promote development? Institute of International Economics.

Morrissey, O., \& Udomkerdmongkol. M. (2012). Governance, private investment and foreign direct investment in developing countries. World Development, 40(3), 437- 445. https://doi.org/10.1016/j. worlddev.2011.07.004

Munemo, J. (2014). Business start-up regulations and the complementarity between foreign and domestic investment. Review of World Economics, 150, 745-761. https://doi.org/10.1007/s10290014-0189-2 
Prasanna, N. (2010). Direct and indirect impact of foreign direct investment on domestic investment in India. Journal of Economics, 1 (2), 77 83. https://doi.org/10.1080/09765239.2010.118 84926

Ranjan, R., \& Kumar, S. (2012). An empirical investigation of the impact of capital inflows on domestic investment in India. Indian Economic Review, 47(1), 15-32.

Rath, B. N., \& Bal, D. P. (2014). Do FDI and public investment crowd in or crowd out private domestic investment in India. The Journal of Developing Areas, 48(3), 269-284.

World Bank. (2002). Global development finance 2002: financing the poorest countries. Global Development Finance. World Bank. 